\title{
EFFECT OF SILVER NANOPARTICLES (AgNPS) PREPARED BY GREEN SYNTHESIS FROM SAGE LEAVES (SALVIA OFFICINALIS) ON MAIZE CHLOROPHYLL CONTENT
}

\author{
1,2,3 Karel SEHNAL, 3,4Yagmur OZDOGAN, 1,2Martina STANKOVA, 1,2Zuzana TOTHOVA, \\ 1,2Dagmar UHLIROVA, ${ }^{1,2}$ Michaela VSETICKOVA, ${ }^{1,2,5}$ Božena HOSNEDLOVA, ${ }^{6}$ Marta KEPINSKA, \\ ${ }^{1,2,3}$ Branislav RUTTKAY-NEDECKY, ${ }^{7}$ Carlos FERNANDEZ, ${ }^{8}$ Vedha HARI, ${ }^{1}$ Jiri SOCHOR, \\ ${ }^{6}$ Halina MILNEROWICZ, 1,2,3,5,6 Rene KIZEK \\ ${ }^{1}$ Department of Viticulture and Enology, Faculty of Horticulture, Mendel University in Brno, Lednice, \\ Czech Republic, EU, sochor.jirik@seznam.cz \\ ${ }^{2}$ Department of Research and Development, Prevention Medicals s.r.o., Studenka-Butovice, \\ Czech Republic, EU, uhlirova@preventionmedicals.cz \\ ${ }^{3}$ Department of Human Pharmacology and Toxicology, University of Veterinary and Pharmaceutical \\ Sciences Brno, Brno, Czech Republic, EU, kizek@sci.muni.cz \\ ${ }^{4}$ School of Pharmacy, Altinbas University, Faculty of Pharmacy, Bagcılar/istanbul,Turkey, \\ ozdoganyagmur@hotmail.com \\ ${ }^{5}$ Department of Food and Feed Safety, Veterinary and Research Institute, Brno, Czech Republic, EU, \\ hosnedlova@post.cz \\ ${ }^{6}$ Department of Biomedical and Environmental Analyses, Faculty of Pharmacy with Division of Laboratory \\ Diagnostics, Wroclaw Medical University, Wroclaw, Poland, EU, zalewska.m@gmail.com \\ ${ }^{7}$ School of Pharmacy and Life Sciences, Robert Gordon University, Garthdee Road, Aberdeen, Scotland, \\ United Kingdom, EU, c.fernandez@rgu.ac.uk \\ ${ }^{8}$ Department of Pharmacy, School of Chemical \& Biotechnology, SASTRA University, India, \\ vedhahari@gmail.com
}

https://doi.org/10.37904/nanocon.2019.8521

\begin{abstract}
The AgNPs have considerable industrial potential and are intensively studied with regard to their antibacterial properties. Using green synthesis, the nanoparticle surface can be coated with molecules that exhibit biologically significant properties. Increased use of nanoparticles enhances the risk of their release into the environment. However, there is still little known about the behaviour of AgNPs in the eco-environment. In this study, the effect of AgNPs prepared by green synthesis on germinated plants of maize was investigated. The effects on germination, basic growth and physiological parameters of the plant were monitored. AgNPs and silver nitrate were applied to maize seedlings ( 5 days in hydroponics system) at concentrations of $1 \mathrm{mg} / \mathrm{L}, 50$ $\mathrm{mg} / \mathrm{L}$, and $150 \mathrm{mg} / \mathrm{L}$. Chlorophyll a and $\mathrm{b}$ content was determined. We found that the growth inhibition of the above-ground parts of plants was about $40 \%$ and AgNPs and silver nitrate had a significant effect on photosynthetic pigments. Chlorophyll a and $b$ content changed with time and concentration.
\end{abstract}

Keywords: Green synthesis, electrochemistry, phytotoxicity, phyto-nanotechnology

\section{INTRODUCTION}

Nanoparticle research is one of the rapidly developing areas of nanotechnology [1]. The most studied nanoparticles are gold (37\%), silver (24\%), and zinc (10\%) nanoparticles (according to WOS analysis) [2]. Silver nanoparticles (AgNPs) are studied because of their antibacterial properties but also exhibit potential antitumor activity. In addition, ultra-stable silver nanoparticles of unique structure have been prepared [3]. In case of their industrial use, however, their possible release into the environment can be expected [4]. To date, 
little is known about the effect of AgNPs on plants [5], although silver ions are commonly used to stimulate growth in explant cultures [6]. The effect of AgNPs on germination [7], morphological changes in maize seedlings [8], plant auxin hormones [9], crop yield and quality of wheat [10,11] were investigated. In addition, biosynthesis of nanoparticles by plants has also been observed [12], which may thus reduce the potential toxicity to the eukaryotic cell. These effects may vary depending on the size, shape and concentration of the nanoparticles and the age and species of the plant. In our previous work we studied the effects of AgNPs and $\mathrm{Ag}$ (I) ions on maize seedlings, we found that AgNPs are toxic to plants [13]. AgNPs are known to induce oxidative stress in eukaryotic cells, disrupt the organelle membranes, cause nucleic acid damage, affect photosystem I (PSI) and mitochondrial metabolism, including the respiratory chain. However, only a very limited number of publications have so far dealt with the interaction between higher plants and AgNPs. It is necessary to study the effects of AgNPs on morphological and physiological changes in plants. The aim of this work was to study the effect of different concentrations of AgNPs on maize (Zea mays) seedling chlorophyll content.

\section{MATERIAL AND METHODS}

Chemicals. Silver nitrate, methanol, $\mathrm{NaCl}$, and other chemicals were purchased from Merck (USA) at a purity $>99 \%$. All chemicals that we used for gel electrophoresis were purchased from VWR (Germany). All plastic materials used (tubes, tips) in this study were purchased from Eppendorf (Hamburg, Germany). Photometry: BS-300 chemical analyser from Mindray (China), cuvettes $5 \times 6 \times 30 \mathrm{~mm}$, optical path $5 \mathrm{~mm}$, a volume of reaction mixture in the cuvette 180-500 $\mu \mathrm{L}$. Photometric detector measuring at wavelengths: $340,405,450$, 510, 546, 578, 630, and $670 \mathrm{~nm}$. Spectrophotometry: a UV/VIS UV-3100PC, VWR (USA) single-beam spectrophotometer was used to record the UV-VIS spectra. The VIS spectrum was measured every $2 \mathrm{~nm}$ in the range of $350-700 \mathrm{~nm}$ in plastic cuvettes with an optical path of $1 \mathrm{~cm}$. The Infinite F50 (Tecan, Switzerland) was used for measurement on a polystyrene microtiter plate (Gama Group a.s., Czech Republic). Electrochemical analysis of silver was performed by differential pulse voltammetry (DPV) method, $0.2 \mathrm{M}$ acetate buffer ( $\mathrm{pH}$ 5), scan from -0.1 to $0.6 \mathrm{~V}$, polarization rate of $25 \mathrm{mV} / \mathrm{s}$. (working carbon electrode, Metrohm. Switzerland). Surface morphology of the nanoparticles was investigated with field emission scanning electron microscopy (FESEM) using operating voltage of $10 \mathrm{kV}$ in the SEM (Zeiss) instrument. Surface charging effect was minimized by coating the samples with gold on copper stubs with a coating instrument. Transmission electron microscope (TEM) and higher resolution TEM (JEOL) were determined on a copper stub with carbon glue and coated with gold before analysis.

Preparation of AgNP., by green synthesis. Dried sage leaves (Salvia officinalis) were purchased (Valdemar Grešík - Natura s.r.o., Czech Republic). The mixture was homogenized by milling to 1-2 $\mathrm{mm}$ particles, then it was extracted and subsequently stirred in ultrapure water $\left(80^{\circ} \mathrm{C}, 60 \mathrm{~min}\right)$ at a ratio of $5 \mathrm{~g} \mathrm{DW} / 100 \mathrm{~mL}$, v/w. The leachate was further centrifuged ( $30 \mathrm{~min}, 4000 \mathrm{~g}$ ) and then mixed with $0.1 \mathrm{M} \mathrm{AgNO}_{3}$ (1:1). The solution was stirred on a magnetic stirrer $\left(80^{\circ} \mathrm{C}, 24 \mathrm{~h}\right)$. The particles were washed with methanol.

Determination of chlorophyll content. Zea mays seeds of the Silen variety were watered with tap water (250 $\mathrm{mL}$, conductivity $485 \mu \mathrm{S} / \mathrm{cm}, \mathrm{pH} 6.6,25^{\circ} \mathrm{C}$ ) and germinated. For the experiment, 7-day-old maize seedlings were selected. The seedlings were then placed into a hydroponic system with 3 litres of cultivation solution. Distilled water was chosen as a negative control. $\mathrm{Ag}(\mathrm{I})$ ions (from silver nitrate) and AgNPs were applied at concentrations of 1,50 , and $150 \mathrm{mg} / \mathrm{L}$. During 5 days of cultivation physiological and morphological examination of plants (every $24 \mathrm{hrs}$ ) was performed. For sample preparation, leaf parts of plants from each day smashed in mortar with acetone and sea sand. After smashing the samples were transferred into $2 \mathrm{ml}$ tubes. This tubes were put into ultrasonic for 10 minutes, multi-rotator for 10 minutes and centrifuged for 10 minutes at $11000 \mathrm{~g}$. Chlorophylls and carotenoids contents were measured as described in [14]. Briefly, chlorophylls and carotenoids were extracted from plant leaves with acetone. Absorbance of the extracts was 
measured using a spectrophotometer. Contents of chlorophyll a $\left(\mathrm{C}_{a}\right)$, chlorophyll $b\left(\mathrm{C}_{b}\right)$, and carotenoids $\left(\mathrm{C}_{\mathrm{x}}+\mathrm{c}\right)$ were calculated using the formula described in [14]. According to spectrophotometer results $C_{a}, C_{b}$ and $C_{x}+c$ values were calculated according to the following formulas:

$$
\begin{aligned}
& C_{a}=12 \times A_{663}-2.69 \times A_{645} \\
& C_{b}=22.9 \times A_{645}-4.68 \times A_{663} \\
& C_{x}+C=4.968 \times A_{440}-0.268 \times\left(C_{a}+C_{b}\right)
\end{aligned}
$$

Statistical data analysis. Experimental work was performed in at least three independent experiments. Each sample in the experiments was analysed at least five times. The obtained data presented in this paper are the average values. All the obtained data were stored in the Qinslab database (Prevention Medicals, Czech Republic). If possible, data were processed and evaluated mathematically and statistically in the Qinslab database. The results were expressed as mean \pm standard deviation (SD). Photos were processed by the ColorTest program, which assigns an intensity to the individual pixels of the studied image in a given color area [19].

\section{RESULTS AND DISCUSSION}

\section{Changes in physiological parameters of plants exposed to AgNPs}

The plants were cultivated in a hydroponic experiment (see in Material and Methods part). The experiment was checked twice a day and samples were taken each day in the morning. Basic physiological parameters were measured. The length of the longest root was measured for each sample. After 120 hours of cultivation, the mean leaf length values were calculated: untreated control $3.33 \mathrm{~cm}$, plants treated with AgNPs $4.00 \mathrm{~cm}$ and plants treated with $\mathrm{Ag}(\mathrm{I})$ ions $2.88 \mathrm{~cm}$. The length of the longest leaf was $23.2,27.0$ and $15.4 \mathrm{~cm}$, respectively. The length of the shortest leaf was $6.0,5.8$ and $7.2 \mathrm{~cm}$, respectively (there were no statistical differences).
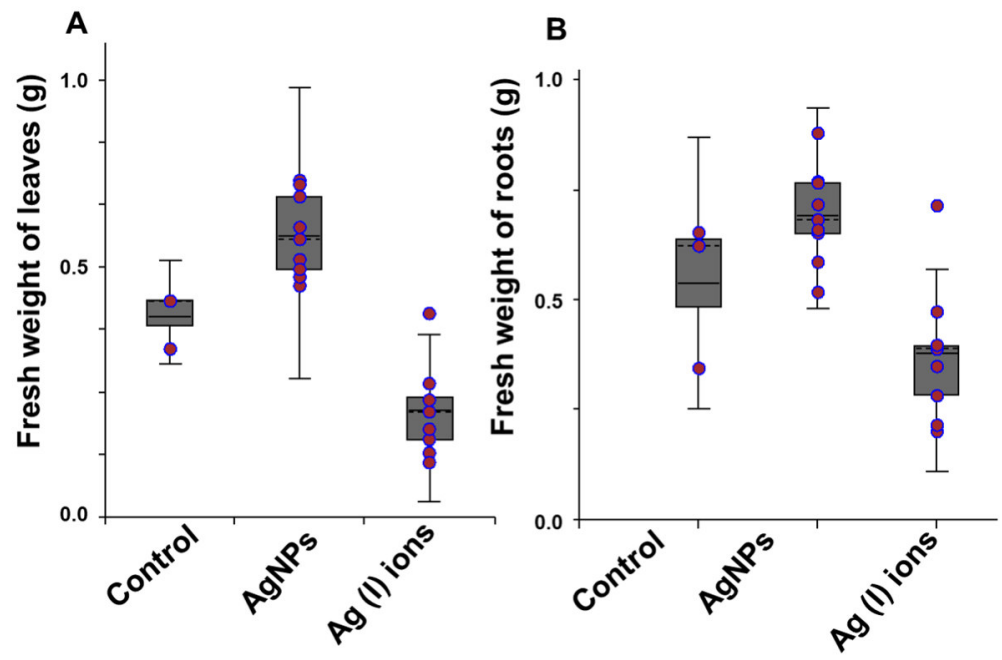

Figure 1 Average cumulative changes (concentrations: 1, 50, $150 \mathrm{mg} / \mathrm{L}$ ) in the effect of AgNPs and $\mathrm{Ag}(\mathrm{I})$ ions on the fifth day of experiment A) fresh weight of leaves; (B) fresh weight of roots. Other experimental details see in Material and Methods part.

Results of the fresh weight of leaves and roots after 120 hours of cultivation are shown in Figure 1. The mean fresh weight values of leaves were calculated: untreated control $0.39 \mathrm{~g}$, plants treated with AgNPs $0.60 \mathrm{~g}$ and plants treated with $\mathrm{Ag}(\mathrm{l})$ ions $0.16 \mathrm{~g}$ (statistically significant differences). The total number of roots was on average: untreated control 11.3, plants treated with AgNPs 12.6 and plants treated with $\mathrm{Ag}(\mathrm{I})$ ions 11.7. The 
shortest roots were on average 1.9, 1.9 and $1.6 \mathrm{~cm}$ long, respectively. The longest roots were 26.0, 34.9 and $21.9 \mathrm{~cm}$ long, respectively. Mean fresh weight of roots was $0.58,0.78$ and $0.38 \mathrm{~g}$, respectively (Figure 1). After administration of AgNPs, plants showed a gradual leaf tip drying and a slight change in leaf and root colour. A significant change in plant growth parameters (growth reduction of about $40 \%$ ) was observed. There was a change in root biomass, but the number of roots remained unchanged. Compared to control, statistically significant differences were found in all studied variants at $95 \%$ significance level. The expected effects of AgNPs phytotoxicity are, in addition to those on the nucleus and mitochondria, also on chloroplasts and thus also on the number of photosynthetic dyes. Figure 2 shows typical chlorophyll spectra after treatment with AgNPs or Ag (I) ions. The records are similar and will be further studied in greater detail.
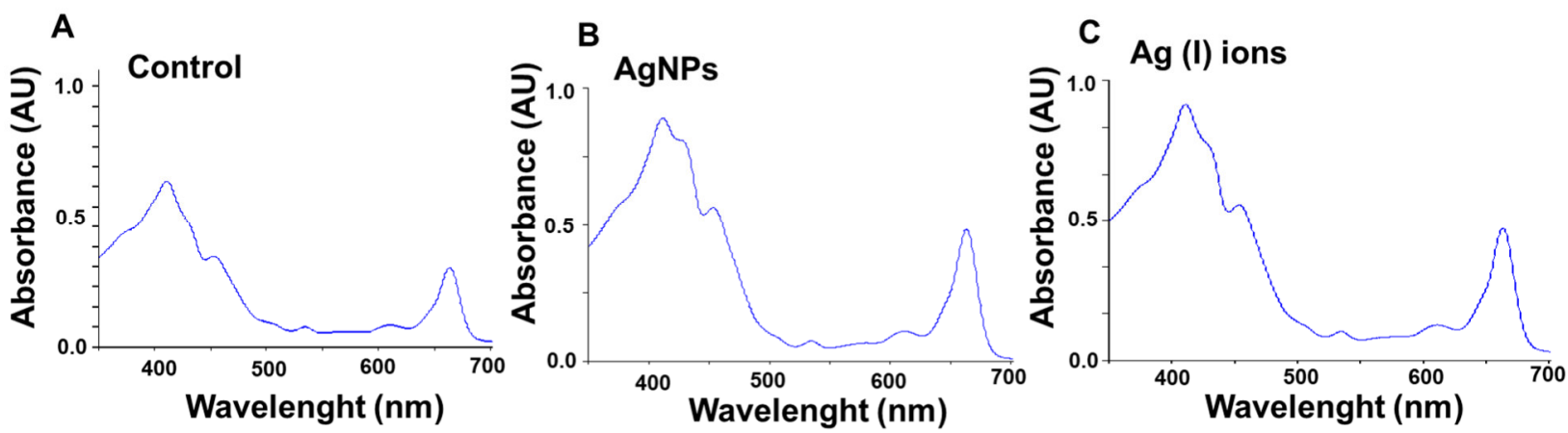

Figure 2 Typical spectra of $Z$. mays leaf extracts for the determination of chlorophylls and carotenoids after 120 hours of the experiment using 0 (A) and $150 \mathrm{mg} / \mathrm{L} \mathrm{AgNPs} \mathrm{(B)} \mathrm{or} \mathrm{Ag} \mathrm{(I)} \mathrm{ions} \mathrm{(C).} \mathrm{Other} \mathrm{experimental}$ details see in Material and Methods part

Furthermore, the amounts of chlorophyll a, chlorophyll b, carotenes and xanthophylls were calculated (see Material and Methods part). The results are shown in Figure 3. We found that the amount of photosynthetic dyes was the following: chlorophyll a untreated control $35 \mathrm{mg} / \mathrm{g}$ of leaf (FW), plants treated with AgNPs 45 $\mathrm{mg} / \mathrm{g}$ of leaf, and plants treated with $\mathrm{Ag}(\mathrm{I})$ ions $30 \mathrm{mg} / \mathrm{g}$ of leaf. The increase in the amout of photosynthetic dyes by more than $20 \%$ in the presence of AgNPs is likely caused by plant defensive reactions due to increased oxidative stress. However, this possible link should be further studied [15]. Amount of chlorophyll b was the following: untreated control: $18 \mathrm{mg} / \mathrm{g}$ of leaf, plants treated with AgNPs $25 \mathrm{mg} / \mathrm{g}$ of leaf, and plants treated with $\mathrm{Ag}(\mathrm{I})$ ions $15 \mathrm{mg} / \mathrm{g}$ of leaf. Amount of carotens was the following: untreated control: $3 \mathrm{mg} / \mathrm{g}$ of leaf, plants treated with AgNPs $5 \mathrm{mg} / \mathrm{g}$ of leaf, and plants treated with $\mathrm{Ag}(\mathrm{I})$ ions $2.5 \mathrm{mg} / \mathrm{g}$ of leaf. A statistically significant difference compared with control was found in all studied variants at $95 \%$ significance level.

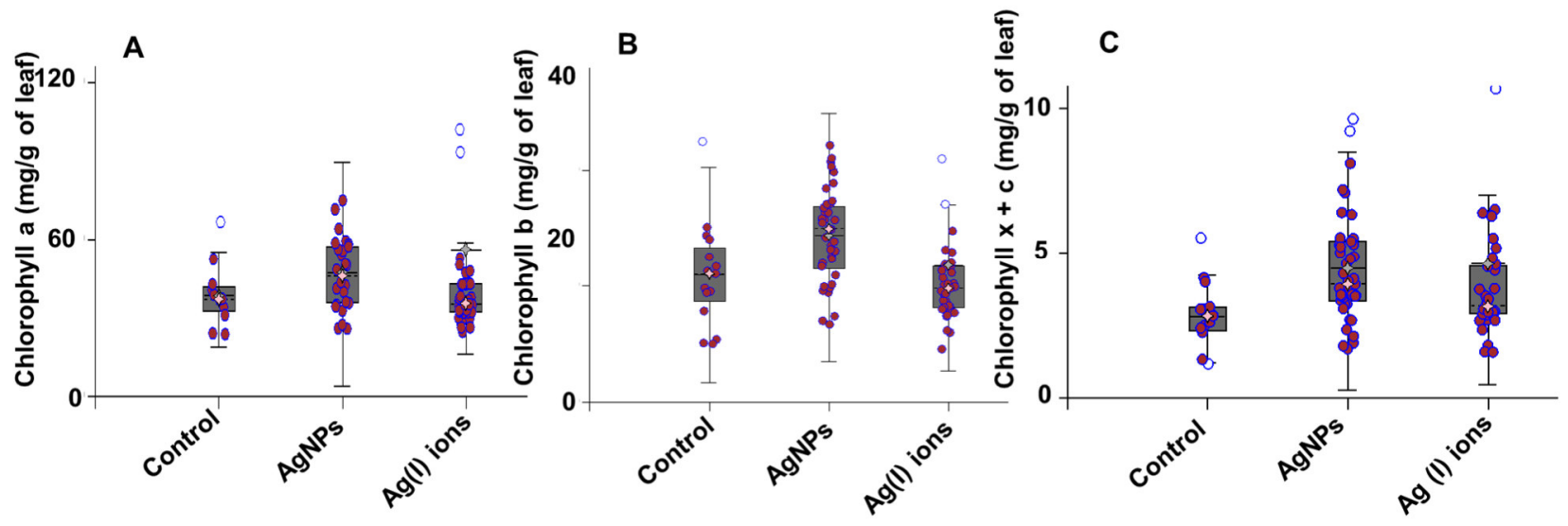

Figure 3 The average content of chlorophyll a (A), chlorophyll b (B) and carotenoids

(C). Other experimental details see in Material and Methods part. 


\section{CONCLUSION}

Silver nanoparticles were synthesized from the sage leaves using green synthesis. AgNPs were biophysically characterized and their phytotoxicity was tested in germinated plants of maize. AgNPs were chemically stable over the course of the experiment and showed the effect on the germinated plants in most of the analysed morphological parameters. We studied the effects of AgNPs and $\mathrm{Ag}(\mathrm{I})$ ions on changes in chlorophyll levels. We found differences between chlorophyll levels in plants treated with AgNPs, in which the chlorophyll content was slightly increased and $\mathrm{Ag}(\mathrm{I})$ ions, in which the chlorophyll content was slightly decreased. The data obtained from the project are very interesting and will be further studied in detail.

\section{ACKNOWLEDGEMENTS}

\section{The work was carried out with the support of the H2020 CA COST Action CA15114, INTER-COST LTC18002.}

\section{REFERENCES}

[1] FADEEL, B., FARCAL, L., HARDY, B., VAZQUEZ-CAMPOS, S., HRISTOZOV, D., MARCOMINI, A., LYNCH, I., VALSAMI-JONES, E., ALENIUS, H., SAVOLAINEN, K. Advanced tools for the safety assessment of nanomaterials. Nat. Nanotechnol., 2018, vol. 13, no. 7, pp. 537-543.

[2] SEHNAL, K., STANKOVA, M., DOCEKALOVA, M., UHLIROVA, D., GARGULAK, M., TOTHOVA, Z., RUTTKAYNEDECKY, B., KIZEK, R. Biofyzikální analýza stříbrných nanočástic připravených zelenou syntézou a využití pro 3D tisk antibakteriálního materiálu. Czech Chem. Soc. Symp. Ser., 2019, vol. 17, no. pp. 66-71.

[3] DESIREDDY, A., CONN, B. E., GUO, J. S., YOON, B., BARNETT, R. N., MONAHAN, B. M., KIRSCHBAUM, K., GRIFFITH, W. P., WHETTEN, R. L., LANDMAN, U., BIGIONI, T. P. Ultrastable silver nanoparticles. Nature, 2013, vol. 501, no. 7467, pp. 399-402.

[4] AKTER, M., SIKDER, M. T., RAHMAN, M. M., ULLAH, A. K. M. A., HOSSAIN, K. F. B., BANIK, S., HOSOKAWA, T., SAITO, T., KURASAKI, M. A systematic review on silver nanoparticles-induced cytotoxicity: Physicochemical properties and perspectives. J. Adv. Res., 2018, vol. 9, no. pp. 1-16.

[5] ZHENG, Y. L., HOU, L. J., LIU, M., NEWELL, S. E., YIN, G. Y., YU, C. D., ZHANG, H. L., LI, X. F., GAO, D. Z., GAO, J., WANG, R., LIU, C. Effects of silver nanoparticles on nitrification and associated nitrous oxide production in aquatic environments. Sci. Adv., 2017, vol. 3, no. 8, pp. 11.

[6] TRIPATHI, D. K., TRIPATHI, A., SHWETA, SINGH, S., SINGH, Y., VISHWAKARMA, K., YADAV, G., SHARMA, S., SINGH, V. K., MISHRA, R. K., UPADHYAY, R. G., DUBEY, N. K., LEE, Y., CHAUHAN, D. K. Uptake, Accumulation and Toxicity of Silver Nanoparticle in Autotrophic Plants, and Heterotrophic Microbes: A Concentric Review. Front. Microb., 2017, vol. 8, no. 7, pp.

[7] YIN, L., COLMAN, B. P., MCGILL, B. M., WRIGHT, J. P., BERNHARDT, E. S. Effects of silver nanoparticle exposure on germination and early growth of eleven wetland plants. PLoS One, 2012, vol. 7, no. 10, pp. e47674.

[8] JAFARI, S., DAVOODI, D., JONOUBI, P., MAJD, A., ALIZADEH, H., SHOBBAR, Z. S. Anatomical assessment of maize (Zea mays L.) seedlings exposed to colloidal silver nanoparticles. Appl. Ecol. Environ. Res., 2018, vol. 16, no. 3, pp. 2391-2401.

[9] THANGAVELU, R. M., GUNASEKARAN, D., JESSE, M. I., S.U, M. R., SUNDARAJAN, D., KRISHNAN, K. Nanobiotechnology approach using plant rooting hormone synthesized silver nanoparticle as "nanobullets" for the dynamic applications in horticulture - An in vitro and ex vitro study. Arab. J. Chem., 2018, vol. 11, no. 1, pp. 48-61.

[10] YANG, J., JIANG, F., MA, C., RUI, Y., RUI, M., ADEEL, M., CAO, W., XING, B. Alteration of crop yield and quality of wheat upon exposure to silver nanoparticles in a life cycle study. J. Agric. Food Chem. , 2018, vol. 66, no. 11, pp. 2589-2597.

[11] POKHREL, L. R., DUBEY, B. Evaluation of developmental responses of two crop plants exposed to silver and zinc oxide nanoparticles. Sci. Total Environ., 2013, vol. 452, no. pp. 321-332. 
[12] SINGH, P., KIM, Y.-J., ZHANG, D., YANG, D.-C. Biological Synthesis of Nanoparticles from Plants and Microorganisms. Trend. Biotech., 2016, vol. 34, no. 7, pp. 588-599.

[13] SEHNAL, K., HOSNEDLOVA, B., DOCEKALOVA, M., STANKOVA, M., UHLIROVA, D., TOTHOVA, Z., KEPINSKA, M., MILNEROWICZ, H., FERNANDEZ, C., RUTTKAY-NEDECKY, B., HOAI, N., OFOMAJA, A., SOCHOR, J., KIZEK, R., An assessment of the effect of green synthesized silver nanoparticles using sage leaves (Salvia officinalis L.) on germinated plants of maize (Zea mays L.). Nanomaterials, 2019, vol. in revision, no. pp.

[14] WELLBURN, A. R. The spectral determination of chlorophyll-a and chlorophyll-b, as well as total carotenoids, using various solvents with spectrophotometers of different resolution J. Plant Physiol., 1994, vol. 144, no. 3, pp. 307-313.

[15] ZHENG, S. M., ZHOU, Q. X., CHEN, C. H., YANG, F. X., CAI, Z., LI, D., GENG, Q. J., FENG, Y. M., WANG, H. Q. Role of extracellular polymeric substances on the behavior and toxicity of silver nanoparticles and ions to green algae Chlorella vulgaris. Sci. Total Environ., 2019, vol. 660, no. pp. 1182-1190. 